Received in revised form: 23. October 2019;

Accepted: 5. November 2019;

Available online: 10. November 2019

\title{
SIGNIFICANCE OF SUSTAINABLE ECO-TOURISM FOR SERBIA'S ECONOMIC DEVELOPMENT
}

\author{
Larisa Jovanović* ${ }^{* 1}$, Dragan Živković*, Milan Jankovićn, Violeta Šiljak ${ }^{* * * *}$, \\ Dragan Toskićs \\ *ALFA BK University, Belgrade \\ ** Faculty of Business Studies and Law, Union - Nikola Tesla University, Belgrade \\ ${ }^{* * *}$ European Center for Peace and Development of UN Peace University, Belgrade \\ ${ }^{*}$ Faculty of Sports and Physical Education, University of Prishtina, Leposavić
}

\begin{abstract}
Sustainable development of eco-tourism in Serbia has great prospects and opportunities for the intensification of entrepreneurship based on natural resources in rural and mountainous areas. In the world after euphoria due to staying in hotelsskyscrapers, ice hotels, boat hotels and other exotic places with Japanese, Thai, Italian and French specialties, tourists return to the gentle landscapes, primal values and ethnic food.

Food producers in Serbia have potential on large areas of fertile soils and pastures, high-quality varieties of crops, good breeds of sheep, pigs, cows, goats and mangules. There is practically no general marketing and promotion of the tourist offer in our country, as well as branding of Serbian food products for placement on world markets. To attract investment, it is necessary to develop Serbian tourism brands and promote eco-tourism in mountainous and rural areas at international fairs.

Hunting, fishing, hiking, trekking and horseback riding, supplemented by the consumption of ethnic food and organic food products, marked with local brands and geographical origin can make a significant contribution to the sustainability of tourism, ecotourism and other forms of entrepreneurship in Serbia.
\end{abstract}

Keywords: eco-tourism, diversification, tourism portfolio, eco-destination, ecofarm, ethno-food, organic agriculture, integrated marketing management, economic development, Serbia.

1 Corresponding author: L. Jovanović, ALFA BK University, Belgrade;

e-mail: larisa.jovanovic@alfa.edu.rs 


\section{Introduction}

The end of the twentieth century was marked with a significant strategic shift from mass tourism to alternative forms of tourism in response to the growing uncertainty caused by the dynamic and structural changes in the tourism economy associated with changing consumer behavior, the rise of environmental awareness in broad sections of society. The sustainable development paradigm is gaining popularity and, as a result, there is growing appeal for sustainable, responsible and balanced development of a green economy that includes eco-tourism. Sustainable eco-tourism, as one of the important conditions for the development of green economy, is based on good ecological sites in clean areas with unpolluted environment (mountain and rural areas, edges of protected areas).

The definition of ecotourism according to the Cambridge English Dictionary: "Ecotourism is a form of tourism to places having unspoiled natural resources, with minimal impact on the environment being a primary concern. It means responsible traveling to natural areas, conserving the environment and improving the well-being of local people."

Important components of eco-tourism are environmental protection and preservation of natural resources and cultural and historical heritage of the tourist destination with the aim of economic development of smaller environments. The development of ecotourism is closely linked to the catering and organic food production. Organic production as an integral part of the green economy complements eco-tourism. Organic farms, as an important condition for food production in catering establishments in tourism eco-destinations, favor the development of eco-tourism. A large number of producers in rural, mountain and Ramsar areas produce health-friendly ethno-food from indigenous raw materials. The need to exploit and preserve the natural potential of our country through the offer of healthy ethno-nutrition contributes to the development of eco-tourism and sustainable mountain tourism, as well as tourism in protected areas (eco-zones, eco-villages, eco-farms). All forms of sustainable eco-tourism can improve the socio-economic position of the Serbian population over time. New marketing approaches give impetus to the development of sustainable eco-tourism.

Tourism potentials in eco-tourism area are still underutilized in Serbia. Development of eco-tourism requires investments in transport infrastructure, as well as improvement of energy infrastructure and reduction of energy dependence of the country through the use of renewable energy sources (Čajka, Jovanović, 2014). Providing secure energy sources (first, by installing solar panels on the roof of houses and also building solar power plants and wind farms) enables rural, mountainous and protected areas to develop eco-tourism, hotel 
industry and hospitality at these destinations (Chavlin et al., 2018; Vujadinović et al. 2013; Joksimović et al. 2013; Pecelj et al., 2010).

The aim of the paper is to examine the natural potentials and opportunities for stable sustainable development of eco-tourism in the Republic of Serbia. The analysis of the work of individual eco-tourism destinations provides examples of the revival of eco-tourism through portfolio diversification and clustering of individual sectors of entrepreneurship.

\section{Potentials for the Development of Eco-Tourism in Serbia}

Serbia has exceptional preconditions for the development of eco-tourism in terms of natural resources, cultural heritage, traditional indigenous food and accommodation in ethno villages, farmhouses and small hotels on the edge of protected areas. Tourists who choose to go on a vacation in the countryside, mountain or near protected areas want to at least briefly leave life in the urban environment, while learning about the traditions and peculiarities of these areas.

In the Republic of Serbia, the number of protected areas is constantly growing. Based on the applied measures of institutional nature protection for more than six decades, the area of protected areas in Serbia covers about $8 \%$ of the territory of Serbia and currently amounts to 662,435 ha. There are 461 protected areas under protection, which are protected under the Environmental Protection Act (EPA, 2004) and the Cultural Property Act (CPA, 1994):

- 5 national parks

- 18 nature parks

- 20 landscapes of exceptional quality

- 68 nature reserves

- 3 protected habitats

- 310 nature monuments

- 38 cultural and historical sites

All these areas can be used as eco-destinations with significant potential for the development of eco-tourism and various forms of entrepreneurship.

Wetlands are protected internationally by the Ramsar Convention (RC, 1971). Ramsar wetlands represent resources of great importance for biodiversity conservation. They provide habitats for migratory bird species, which, because of their seasonal movements and cross-country movements, are considered international resources. Also, these areas are of exceptional value for the development of many forms of tourism: scientific, sports, recreational, gastronomic, etc. 
In the Republic of Serbia, the local population of Ramsar areas and surrounding villages has direct and indirect profits from the growth of this type of ecotourism (Ilić, Trandafilović, Jovanović, 2017; Stojnić, 2015).

Zasavica is a very visited nature reserve. In addition to individual tourist visits, Zasavica is very popular for student excursions with a boat ride accompanied by teachers and biologists - a guide. Thus, the revenue from tourist visits from tickets alone is about 2 and a half million dinars a year. Also great is the profit from the catering services, and also from the sale of souvenirs and ethnofood: goat's milk, cheeses, processed meat of mangulica, etc. There is also a mini zoo in Zasavica with rare animals (Zasavica, 2019).

In Obedska swamp, the average ticket price is 90.00 dinars and the number of visitors is about 20,000 a year. Ticket revenue of about $2 \mathrm{mln}$. dinars represent only a fraction of the profits from the entire tourist offer (boat rides, catering services, souvenir sales) (OB, 2019; OB 2016; OB, 2010).

The Imperial swamp is visited by about 13,000 guests annually, which brings in ticket revenue of approximately one and a half dinars. Also, consideration should be given to earnings from catering, souvenir sales, tourist boat trips and guide services (CB, 2019).

In the vicinity of Palic on Ludash Lake, the number of visitors was more than 500 during 2017. (LJ, 2016; LJ, 2014). The profit from the tickets alone amounted to over 50 thousand dinars annually. In addition to collecting tickets, they also make money from small businesses and entrepreneurship (catering, hotels, trade, crafts, souvenir production and marketing, marketing) (BradićMartinović, Miletić, 2018; MHSW, 2018). The zoo in Palić also contributes to the attractiveness of the area.

The Kovilj-Petrovaradin area is visited annually by about 100 people, free of charge. The total profit from tourist visits is formed by the payment of Novi Sad-Kovilj return bus tickets and the payment of services in the reserve from hunting and fishing, although the tourist utilization of the reserve is not large (KPR, 2019).

\section{Phases for the Development of the Tourist Destination}

Every tourist product on the market lives for a certain amount of time, and then pushes it out of the market for another perfect one. This phenomenon is related to the concept of the life cycle of tourism products. The product life cycle is the time from when the product first appeared on the market until its discontinuation in the market. The life cycle describes changes in sales and profit indicators over time. 
It is common for a tourist destination to go through various stages of development over time, which implies different rates of growth, as measured by the number of tourist arrivals and nights, as well as the number of rooms in accommodation facilities. Depending on the dynamics of the tourist destination development, we can create different conceptual models of development. One of the most widely accepted approaches to the evolution of a tourist destination is based on the basics of the traditional product life cycle concept.

According to the mentioned model, tourist destinations go through an evolutionary cycle consisting of several stages: exploring a new product and engaging in market flows, development, consolidation, stagnation and a recession phase with declining arrangement sales and total profits (Pic.1).

The $R \& D$ phase is characterized by a slight increase in sales. This phase may be unprofitable because of the large investment and marketing costs and the small number of arrangements sold.

The growth phase of arrangement sales is characterized by product recognition by consumers, increased profits, a decline in the relative share of marketing costs, and the stability of arrangement prices. The destination becomes a member of a complex and turbulent tourism industry with representatives from all major franchisors and chains. Pointing out the importance of preserving the resource base, introducing attractive forms of tourproducts, as well as preserving the cultural identity of eco-destination are significant features that characterize the maturity stage (Zivkovic, 2018).

At maturity, sales growth slows and even begins to decline, because the product has already been purchased by most potential customers, competition is intensifying, marketing costs are usually rising, arrangement prices are falling, profits will stabilize or decrease. It is possible to expand this phase by upgrading the touring product segments or expanding the market.

In a phase of stagnation and then a decline in tourist interest, the competitiveness of the destination is reduced. This is the reason for the decrease in the number of visitors and the further narrowing of the market. At this stage, the range of tourist services within the destination should be expanded, which is most often achieved by undertaking numerous investment activities in structural and sectoral change, including new facilities and new forms of tourism. The recession in the market is manifested in a sharp decline in sales and profits. Product modernization, lower prices, higher marketing costs can only prolong this phase.

The life cycle curve pattern remains more or less the same for most tourism products. However, the length of time and the intensity of the transition from one phase to another vary depending on the specificity of the tourism product and the target market. The transition from phase to phase is going on fairly 
smoothly, so the marketing department must closely monitor changes in sales arrangements and profits to capture the boundaries of the stages and make changes to the marketing program accordingly.

It is important to determine the stage of maturity and saturation, and especially the phase of recession, because keeping a morally obsolete tourism product on the market is not financially efficient and is detrimental to the prestige of the firm. Therefore, it is necessary to choose the right time to enter the market with some new or modernized tourism product. If the demand for another company's turbine product is already declining, it is not rational to enter the market with a similar product.

\section{Volume of sales} and profit

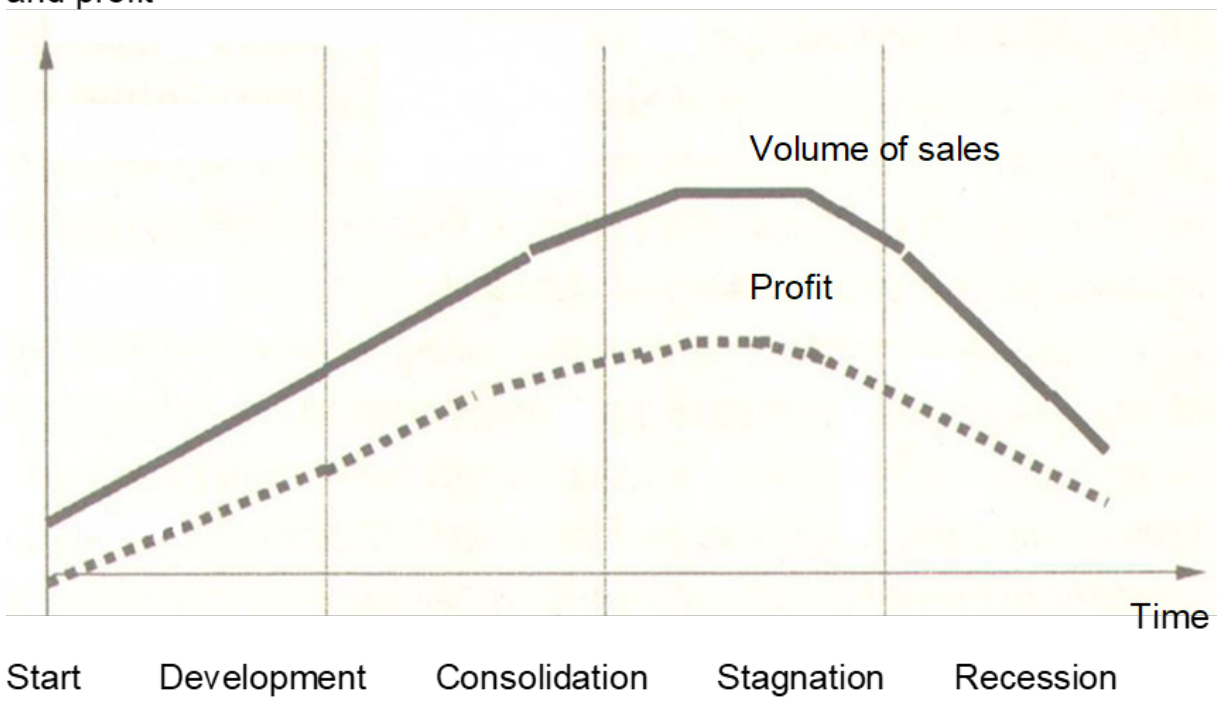

Figure 1. Tourism product life cycle

Different stages of the tourism product lifecycle require the use of different marketing strategies regarding the different characteristics of the tourism product lifecycle stages. To maximize the growth period of a tourism product, a travel agency can use the following approaches:

- improving the quality of tourism products

- issuing a modernized tourism product

- penetrating new market segments

- use of new distribution channels

- diversion of advertising

- timely lowering prices to attract additional customers. 
By using these strategic techniques, a travel agency can strengthen its competitive position in the market.

The development of a tourism product within its life cycle is a prerequisite for marketing activities. Over time, the range of tourism products typically increases. The product range is a group of tourist products that are, by their nature, suited to the needs of their customers. The planning of a range of tourism products must be done based on their life cycle and market positioning. When determining product policy in the field of tourism, it should be borne in mind that the same product in different target markets may be at different stages of the life cycle.

Most travel companies sell a variety of travel products. It is desirable for each company that its tourism products be at different stages of the life cycle. When the sale of one tourism product declines and ceases to be profitable, the sale of another will help offset losses and will not affect the stability of the financial position of the tourism company.

Studying the activities of competitors, analyzing the strengths and weaknesses of the tourism company, as well as surveying customers about the quality of services, allows to improve the position of the tourist company in the market.

\section{Creating a Competitive Position of the Tourist Destination for the Eco-Tourism Development}

In the stagnation phase, it is necessary to explore the possibilities of increasing the attractiveness of the tourist eco-destination through diversification of the tourism portfolio.

Portfolio diversification can be achieved through a combination of classic tourism forms associated with natural resources of a particular eco-destination (for example, mountain eco-tourism), with rural, gastronomic or congress tourism. In this way we can expand the market niche of the tourist destination. Development of special forms of tourism, especially religious, can complement portfolio of a large number of tourist destinations in Serbia and many other countries in the world.

In addition to the primary tourism form, later in the diversification of the portfolio, it is necessary to include other forms of eco-tourism that will innovate tourism eco-destinations and thus increase the number of target groups of tourists and improve the profitability of tourism company (Fig. 2).

Spa mountain resorts can also serve to open up new eco-destinations or to diversify portfolios and cluster with other forms of ecotourism (Markovic et al., 2018). 
Evident and unbreakable relationship and a common interest of sports and tourism, as a consequence, has lead to developed of specific industry branch sports tourism (Stefanović et al., 2017). This type of tourism is conceptualized by considering sport as a tourist attraction, that is, highlighting and defining the quality of sport that united represent a unique contribution to tourism.

Due to its planetary importance, sport is considered the largest global phenomenon in the world, and tourism is the most extensive economic activity in the world. In recent years, sports and tourism experts have begun to understand the significant potential of sports tourism and aggressively encourage its marketing.

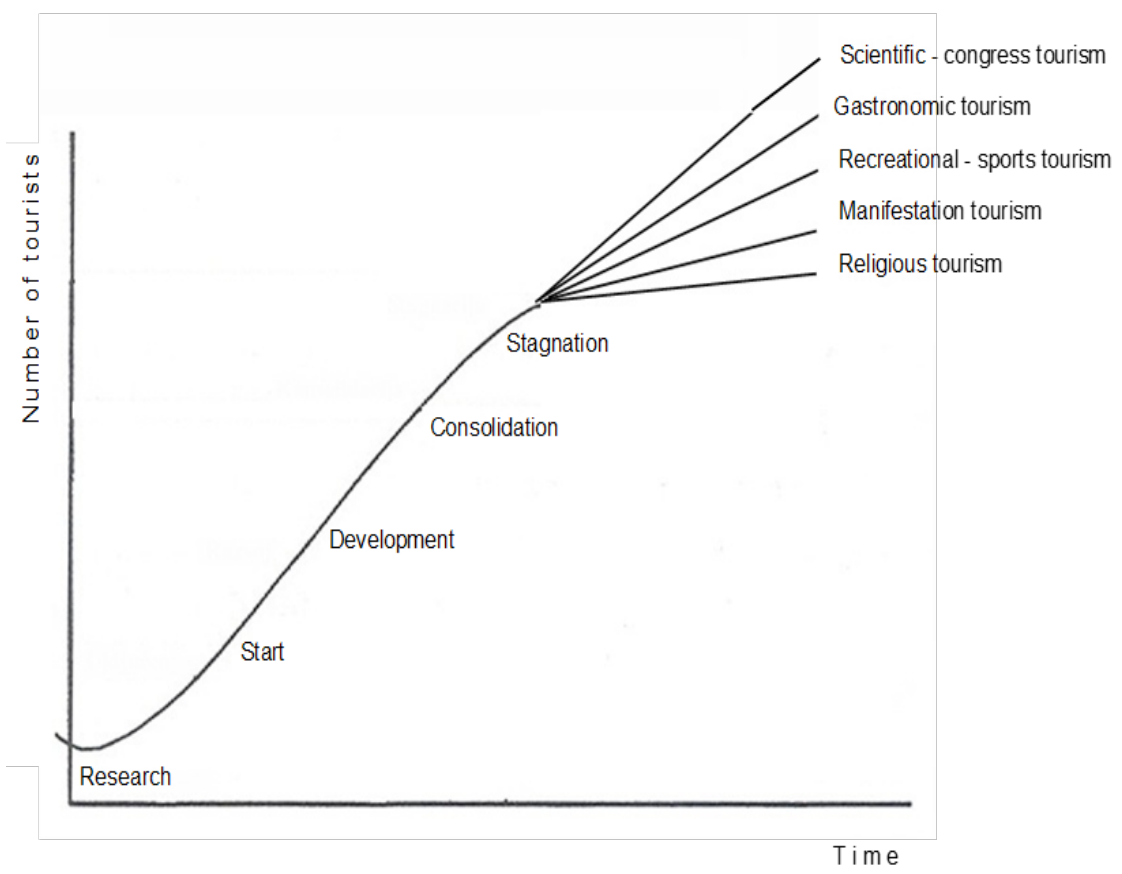

Figure 2. Life cycle of tourism product and tourism destination portfolio diversification

(Source: Jovanovic, Zivkovic, 2018)

While the number of international trips is continuously increasing, and with significant growth rates, geographical spread and the number of sports-related trips are becoming one of the fastest growing forms of tourism, as evidenced by estimated growth rates (Peigi, 2017).

In addition to the many forms of sports tourism with competitive sports content and sports activities and training, eco-tourism also includes recreational forms of tourism and luxury sports tourism. However, there are other selective types and forms of tourism that have the characteristics of sports tourism, e.g. 
nautical tourism, hunting, fishing and health-preventive tourism. These types and forms of tourism have other characteristics besides sports motives, so it is impossible to classify them exclusively in the field of sports tourism. However, in designing their tourist offer, it is necessary to take into account the appropriate sports and recreational facilities, especially in the nautical and health-preventive form of ecotourism.

A large number of different geographic and geomorphologic potentials in Serbia, relief diversity, mountain ranges and slopes, richness of water resources, are ideal prerequisites for the development of eco-sports tourism at numerous eco-destinations (Šiljak et al, 2014).

There is a long list of sports branches that can be practiced at eco-tourist destinations during the holidays: fishing, skiing, extreme sports like climbing, paragliding, jumping jumps, mountain biking, etc.

Angelkova (2012) states trekking or hiking tourism and cycling, equestrian tourism, river eco-tours and speleotourism as sub-branches of sports eco-tourism. Hunting and fishing tourism and sport tourism can be defined as separate branches of ecotourism. Following more and more demanding requests of sports and sports recreation fans, tourism, hospitality and sports workers must be prepared to offer potential visitors adequate sports programs, impeccably arranged sports facilities, a variety of nutrition programs, as well as complex conditions for engaging in sports activities in order to increase the profit and profitability of tourists eco-destination (Stefanović et al., 2017).

In each of the mentioned stages of the life cycle of a tourist destination, it is possible to use certain strategic options in order to gain or maintain a position in the market, i.e. to significantly improve competitive advantage, which is presented in Table 1.

Table 1. Tourist destination life cycle and strategic options

\begin{tabular}{|c|c|c|c|c|}
\hline $\begin{array}{c}\text { Product } \\
\text { Life Cycle }\end{array}$ & $\begin{array}{c}\text { Destination } \\
\text { Life Cycle }\end{array}$ & $\begin{array}{c}\text { Product } \\
\text { Options }\end{array}$ & $\begin{array}{c}\text { Market Share } \\
\text { Options }\end{array}$ & $\begin{array}{c}\text { General } \\
\text { Strategies }\end{array}$ \\
\hline $\begin{array}{c}\text { Development of } \\
\text { a new product }\end{array}$ & $\begin{array}{c}\text { Early stages of tourism } \\
\text { (research) }\end{array}$ & $\begin{array}{c}\text { Development of new } \\
\text { products }\end{array}$ & $\begin{array}{c}\text { Occupying a place in the } \\
\text { new market }\end{array}$ & $\begin{array}{c}\text { Growth, portfolio } \\
\text { diversification }\end{array}$ \\
\hline Implementation & Inclusion & $\begin{array}{c}\text { Sales of new and } \\
\text { existing products }\end{array}$ & $\begin{array}{c}\text { Maintaining market share, } \\
\text { entering new markets }\end{array}$ & $\begin{array}{c}\text { Differentiating, } \\
\text { focusing }\end{array}$ \\
\hline $\begin{array}{c}\text { Growth and } \\
\text { stagnation }\end{array}$ & $\begin{array}{c}\text { Maturity (consolidation } \\
\text { and stagnation) }\end{array}$ & $\begin{array}{c}\text { Sales of new and } \\
\text { existing products }\end{array}$ & $\begin{array}{c}\text { Maintaining } \\
\text { market share }\end{array}$ & $\begin{array}{c}\text { Maintaining market } \\
\text { position, status quo }\end{array}$ \\
\hline $\begin{array}{c}\text { Declining } \\
\text { market sales }\end{array}$ & Declining & $\begin{array}{c}\text { Withdrawal of an old } \\
\text { product }\end{array}$ & the market niche & Change of use \\
\hline $\begin{array}{c}\text { Innovation } \\
\text { Substitution }\end{array}$ & $\begin{array}{c}\text { Diversification of the } \\
\text { portfolio of services } \\
\text { and new forms of } \\
\text { tourism }\end{array}$ & $\begin{array}{c}\text { Expanding the range of } \\
\text { products and services; } \\
\text { investing in product } \\
\text { performance }\end{array}$ & Finding new markets & $\begin{array}{c}\text { Targeting the 'status } \\
\text { area', differentiating } \\
\text { and introducing new } \\
\text { services }\end{array}$ \\
\hline
\end{tabular}


Tourism eco-destinations are competitive when they have the capacity to attract visitors and provide them with satisfactory services in a cost-effective manner while improving the well-being of the hosts and conserving natural and cultural resources.

From an empirical perspective, the Travel and Tourism Competitiveness Index, which measures the competitiveness of 140 destinations in attracting international tourists, suggests that the main determinants of tourist destination competitiveness are:

- cultural and natural resources of destinations;

- availability of adequate infrastructure with all tourism facilities to satisfy tourists and

- a sound and affordable regulatory framework for travel and tourism.

Some of these features make destinations attractive to tourists, allowing them to achieve a differentiated position (such as natural resources or cultural heritage) in tourism markets, while others, however, allow destinations to achieve competitive advantages in the long run through the introduction of new tourism products and diversification portfolio. Accordingly, it is necessary to achieve two conditions, in order to ensure destination competitiveness. These are the establishment of an appropriate regulatory framework for travel and tourism and the provision of basic infrastructure.

Successful business within the eco-destination depends on the work of travel agencies, food manufacturers, souvenirs, trade companies, as well as organizations that, in addition to accommodation, provide quality programs for trips to places with cultural and historical monuments, visits to monasteries and sites of preserved geological heritage, and also river and lake excursions.

However, this is not enough if a tourist site as an eco-destination is not organized. For the successful development of tourist eco-destinations, everything must work perfectly: from accommodation facilities, parking spaces, to quality water supply, good access roads and public order organization and guide services. An indicator of the best competitiveness for eco-destination is that the destination has sustained growth over time as expressed by the number of tourist visits.

The main predictors of sustainable economic growth in eco-destinations are:

- affinity for travel and eco-tourism;

- guaranteeing security at the destination;

- existence of a favorable regulatory framework for eco-tourism;

- environmental sustainability and

- price competitiveness. (WEF, 2018), 
Not only above-mentioned conditions are crucial for the development of eco-tourism. Sustainable eco-tourism relies on many other components of a sustainable green economy: organic food, renewable energy, sustainable waste management.

Finding models for financing solar systems in rural and mountainous areas can solve population's problems with sustainable energy supply (Dašić, Anufrijev, 2018). The use of other renewable energy sources (wind energy and small watercourses) in rural areas also requires the elaboration of a financing model by banks or an investment by private investors. Development of publicprivate partnership in Serbia is necessary in the development of eco-tourism, as well as in all other segments of the green and circular economy.

Recycling and reuse technologies in the circular economy are contributing to the reduction of landfill waste to protect land and water resources, composting for organic food production and the development of sustainable eco-tourism in Serbia.

Joint orientation of development programs for production, sale and promotion of healthy ethno-food in our country on the principles of green marketing is the optimal strategy for development of market of healthy food in the development programs of production, sale and promotion of ethno-food within the tourism sector. Joint programs for the production, sale and promotion of health food in Serbia are effectively implemented solely by applying the concept of sustainable marketing management (Čajka, Jovanović, 2014, 2017; Čajka et al, 2017).

There are many other issues that are important for the successful functioning of a tourist destination, among which is a well-organized informative and adequately created promotional company using all modern marketing achievements.

After reviewing the most significant contributions explaining the determinants of competitiveness of tourism eco-destinations, additional activities of destination managers should be analyzed. Basic activities such as planning of tourist destination development, in the long term, as well as destination marketing, in the short term, achieve provision of the right framework for the sustainable development of eco-destination tourism activities.

Competitive and comparative advantages are taken into account when potential visitors compare destinations, and as a result, some destinations are better positioned than others in the minds of tourists. Tourism demand depends on destination branding. This is especially true when destination digital marketing strategies are increasingly relying on the ICT sector's social media to broadcast a unique and attractive destination image. 


\section{Conclusion}

Sustainable development promotes the eco-system's natural resources and also highly valorizes human resources and financial investments in environmental protection, as well as economic development for the benefit of existing and future generations. The sustainable development paradigm includes business strategies for entrepreneurship within eco-tourism and related activities, such as organic food production that focuses on the care of human health and conservation of eco-systems. An indispensable part of modern eco-tourism is the supply of healthy food, which is consistent with ensuring the biological survival of humanity. Modern eco-tourism requires preserved natural resources and products created in environmentally friendly environments (mountains, villages, protected areas). Our country has all these conditions for the development of eco-tourism.

The concept of sustainable development of eco-tourism is slowly being accepted in Serbia as well. Eco-tourism becomes a chance to protect biodiversity, but also an opportunity for young people, who through their work can contribute to Serbia's economic development. The development of eco-tourism contributes to the protection of nature and rational use of natural resources, reduction of unemployment and poverty, conservation of water, air and land, increase of competitiveness and markets conquest, but also the development of entrepreneurship. The development of eco-tourism destinations and the diversification of the tourist services portfolio opens the possibility for development of new types of businesses and revitalization of old forgotten trades.

A careful analysis of the natural resources of the eco-destination enables diversification of the portfolio of tourism services in order to expand the target groups of tourists and the sustainable green growth of eco-tourism in the Republic of Serbia.

Marketing for attracting investments in eco-tourism will contribute to the revitalization of mountainous and rural parts of our country and the development of sustainable eco-tourism and entrepreneurship. Marketing management must be activated in order to promote environmental science, educate population and popularize new directions in science (green economy, green growth, circular economy) to keep citizens ready for the challenges we are facing in the time of climate change and global environmental problems. 


\section{References}

Angelkova, T. (2012). The role of specific types of tourism in the revitalization of the border areas between Serbia and Macedonia. Doctoral dissertation, Belgrade: Singidunum University.

Bradic-Martinovic, A., Miletic, B. (2018). Responsible and sustainable tourism development in Serbia - Palic Eco-Tourism Park, Ecologica, 26 (92), 777-781.

CB (2019). Special Nature Reserve "Imperial Bar", http://visitzrenjanin.com/ special-reserve-natural-car-bara/, accessed 24.11.2019

Tchaika, Z., Jovanovic, L. (2014). Sustainable Marketing Management, Belgrade: Ecologica, 21 (75).

Tchaika, Z., Jovanovic, L. (2017). The role of marketing management in sustainable development. Ecologica, 24 (88), 1015-1019.

Čajka, Z., Jovanovic, L., Radosavljevic, M. (2017). Principles of Sustainable Marketing Communications, Ecologica, 24 (87), 683-687.

Cavlin, M., Skrbic, S., Tepavac, R., Prodanovic, R. (2018). Analysis of the Financing Model of Independent Solar Systems of Households in Rural Areas of the Republic of Serbia, Ecologica, 25 (90), 307-314.

Dasic, G., Anufrijev, A. (2018). Determinants of Green Economy Development and Promotion in Ecotourism, Ecologica, 25 (92), 805-810.

Ilic, B., Trandafilovic, I., Jovanovic, L. (2017). Building a Spa Destination Brand of Serbia, Ecologica, 24 (88), 910-914.

Joksimović, M., Golić, R., Vujadinović, S., Šabić, D., Popović, D. and Barnfield, G. (2013). Restoring Tourist Flows and Regenerating City's Image: The Case of Belgrade, Current Issues in Tourism, 17(3): 220-233, WOS:000334036300002.

Jovanovic, L., Zivkovic, D. (2018). Sustainable development of tourism by diversification of the tourism portfolio, In: Bevanda V., Štetić S. (Eds.), Modern Management Tools and Economy of Tourism Sector in the Present Era, 3rd International Thematic Monograph, Association of Economists and Managers of the Balkans in cooperation with the Faculty of Tourism and Hospitality, Ohrid, Macedonia. Belgrade, pp. 205-219. DOI: https://doi.org/10.31410/ tmt.2018.205.

KPR (2019). Special Nature Reserve "Koviljsko-Petrovaradin rit", http: // www. vojvodinasume.rs/ponuda/srp-koviljsko-petrovaradinski-rit/, accessed $24 / 11 / 2019$

LJ (2014). Decision on fees for the use of the protected area of SRP "Ludaško jezero" ("Official Gazette of RS", no .: 14/2014) 
LJ (2016). Report on the implementation of the Management Program of the SRP "Ludaško jezero" for the year 2016, PE "Palic-Ludaš". http:/ / www.palic-ludas. rs/documents/ pages / 92_report_srp_ludasko_zero_ministarstvo_2016. pdf.

Markovic, S., Bozovic, S., Vukoicic, D., Ristic, D. (2018). Bioclimatic Resources of Mountain Mountain Resorts in Function of Green Tourism Development of Serbia, Ecologica, 25 (90), 418-423.

MEPIEP (2018). Ministry of Environmental Protection, Institute for Environmental Protection, http://www.zzps.rs/novo/index. php?jezik=en\&page=protecting_natural_basic (February 25, 2018)

OB (2016). Decision on Fees for the Use of the Protected Area of SRP "Obedska Bara" (Official Gazette of RS", No: 92/2016)

OB (2010). Management Plan of SRP “Obedska Bara" 2011-2020 (2010), JP Vojvodinašume, ŠG Sremska Mitorvica. http:/ / www.vojvodinasume.rs/wpcontent/uploads/2012/04/Plan\%20 management $\%$ 20SRP\% 20Obedska\% 20bara.pdf, accessed 24/11/2019

OB (2019). Special Nature Reserve "Obedska Bara", https:/ / www.vojvodinasume. rs/ environmental-protection / obedska-bara, accessed 02.11.2019

Pecelj, M., Mandić, D., Pecelj, J., Lukić, B. and Šabić, D. (2010). Informational Technology in Bioclimate Analysis of Višegrad for Health Spa Tourism, In Dondon, P. and Martin, O. (eds.): Mathematics and Computers in Science and Engineering (Book series), Intern. Conf. on Education and Educational Technologies, Scientific and Engineering Academy and Society, Athens, 211214, WOS:000299968900062

Peigi, L. (2017). The Ecological Sports Tourism Tourists Behavior Investigation The Case of Liuxi River National Forest Park in Guangzhou. Chinese Studies, $6,132-142$.

RK (1971). Convention on Wetlands of International Importance especially as Waterflow Habitat, Ramsar, Iran, 2.2.1971 as amended by the Protocol of 3.12.1982 and the Amendments of 28.5.1987, https://www.ramsar.org/sites/default/files / documents / library / current_convention_text_e.pdf.

Stefanovic, R., Siljak, V. Karaleic, S., Djurovic, D., Mekic, B. (2017). Sustainable Development at the Rio 2016 Olympic Games, Ecologica, 24 (86), 344-347.

Stojnić, N. (Editor) (2015). Economic evaluation of ecosystem services of the Special Reserve of Nature "Koviljsko-Petrovaradin rit". Novi Sad: Provincial Institute for Nature Protection.

Šiljak, V., Parčina, I., Begović, M., Ahmić, D., (2014). Sport and Environment, Ecologica, 21 (75), 515-518. 
Vujadinović, S., Šabić, D., Joksimović, M., Golić, R., Gajić, M., Živković, Lj. and Milinčić, M. (2013). Possibilities for Mountain-based Adventure Tourism: the Case of Serbia?, Bulletin of Geography: Socio-economic Series (19): 99-111, DOI:10.2478/bog-2013-0007.

WEF (2018). World Economic Forum, Davos. https://www.weforum.org/focus/ davos-2018, accessed 11/23/2019.

Zivkovic, D. (2018). Managing a Tourism Destination from a Sustainable Development Aspect, Ecologica, 25 (91), 827-832.

Zasavica (2019). Special Nature Reserve "Zasavica" (www.zasavica.org.rs), accessed 02.11.2019 